\title{
PENGARUH JUMLAH TABUNGAN WADIAH DAN DANA INVESTASI TIDAK TERIKAT TERHADAP PIUTANG MURABAHAH PT. BPRS GOTONG ROYONG SUBANG
}

\author{
Angga Kelana \\ Alumni UIN Sunan Gunung Djati Bandung \\ Jl. A.H. Nasution No. 105 Bandung \\ Email: anggakelana262@gmail.com
}

\begin{abstract}
Abstrak
Tulisan ini bertujuan untuk menunjukkan seberapa besar penga ruh tabungan Wadiah dan dana investasi tidak terikat terhadap piutang murabahah baik secara parsial maupun simultan pada PT. BPRS Gotong Royong Subang. Variabel yang digunakan dalam ini adalah tabungan Wadiah, dana investasi tidak terikat dan piutang murabahah. Analisis statistik yang digunakan adalah regresi linier, pengujian hipotesis melalui uji F, korelasi dan determinasi, dimana Wadiah dan dana investasi tidak terikat menjadi variabel independen se dangkan piutang murabahah sebagai variabel dependen. Hasil analisis membuktikan bahwa secara simultan tabungan Wadiah dan dana investasi tidak terikat memiliki hubungan positif terhadap piutang murabahah dengan $f_{\text {hitung }}>f_{\text {tabel }}(13,387>4,26)$ dengan tingkat signifikasi $(0,002<0,05)$.
\end{abstract}

\section{Kata Kunci:}

Tabungan Wadiah, Dana Investasi Tidak Terikat dan Piutang Murabahah

\section{A. Pendahuluan}

Bank syariah adalah bank yang dalam menjalankan usahanya berdasarkan pada prinsip-prinsip syariat Islam. ${ }^{1}$ Sejak awal kelahirannya, tujuan utama didirikannya bank syariah tidak lain sebagai upaya kaum muslimin untuk mendasari seluruh aspek kehidupannya berdasarkan Al-Qur'an dan As-Sunnah, termasuk dari segi ekonominya. Upaya ini terlihat dimana Pakistan dan Malaysia menggunakan sistem profit and loss sharing sekitar tahun 1940-an untuk mengelola dana haji secara nonkonvensional. Sedangkan di Kairo Mesir, tahun 1963 didirikan lembaga keuangan pedesaan yang bernama Mit Ghamr Savings Bank atau biasa disebut Mit Ghamr Bank yang dipelopori oleh seorang

${ }^{1}$ Ely siwanto dkk, Manajemen Perbankan Konvensional Dan Syariah, (UIN Malang Press, 2008), hlm. 125 
ekonom bernama Ahmad El Najj.2 Setelah itu, bank Islam berkembang dengan pesat di berbagai negara baik yang berpenduduk mayoritas maupun minoritas muslim.

Produk-produk pendanaan bank syariah ditujukan untuk mobilisasi dan investasi tabungan untuk pembangunan perekonomian dengan cara yang adil shingga keuntungan yang adil dapat dijamin bagi semua pihak. Tujuan mobilisasi dana merupakan hal penting karena islam secara tegas mengutuk penimbunan tabungan dan menuntut penggunaan sumber dana secara produktif dalam ranggka mencapai tujuan sosialisai ekonomi islam. ${ }^{3}$ Salah satu bentuk penghimpunan dana yang biasa ditawarkan oleh bank syariah biasanya dalam bentuk produk akad Wadiah dan mudharabah, dimana akad ini dapat diterapakan pada kegiatan penghimpunan dana berupa giro, tabungan, deposito maupun dalam penerbitan sertifikat berharga.

Tabungan Wadiah merupakan titipan pihak ketiga pada bank syariah yang penarikannya dapat dilakukan setiap saat menurut syarat tertentu. ${ }^{4}$ Prinsip Wadiah yang lazim digunakan dalam perbankan syariah adalah Wadiah yad dhamanah dan biasa disingkat dengan Wadiah. Dengan kata lain tabungan Wadiah dapat diartikan sebagai produk pendanaan pada bank syariah berupa simpanan dari nasabah dalam bentuk tabungan dalam rangka untuk menjaga keamanan dan memberikan kemudahaan kepada pemakainya.

Simpanan mudharabah adalah akad antara pemilik modal (harta) dengan pengelola modal tersebut, dengan syarat bahwa keuntungan diperoleh kedua belah pihak sesuai jumlah kesepakatan. ${ }^{5}$ Akad mudharabah khususnya mudharabah al muthlaqah atau di Bank Pembiayaan Rakyat Syariah (BPRS) sering juga disebut Dana Investasi Tidak Terikat biasanya hanya terdiri dari tabungan dan deposito. Investasi ini biasanya sering digunakan bank syariah ketimbang investasi terikat karena bank sebagai mudharib diberikan kebebasan mutlak dalam hal pengelolaan investasinya. Dana Investasi Tidak Terikat dapat diartikan sebagai dana pihak ketiga terhadap bank untuk dikelola tanpa ikatan

2 Rizal dkk. Akuntansi Perbankan Syariah, (Jakarta: Salemba Empat, 2007), hlm.

${ }^{3}$ Ascarya, Akad Dan Produk Bank Syariah, (Jakarta: PT Raja Grafindo Persada, 2012), hlm. 112

${ }^{4}$ Rizal dkk. Akuntansi Perbankan hlm. 59

${ }^{5}$ Hendi Suhendi. Fiqh Muamalah, (Jakarta:PT Raja Grafindo Persada, 2014).138 
atau dikelola secara bebas sesuai syariah dengan adanya timbal balik dari pihak bank terhadap pihak pemilik dana.

Tabungan mudharabah adalah simpanan yang penarikannya hanya dapat dilakukan menurut syarat tertentu yang disepakati, tetapi tidak dapat ditarik dengan cek atau alat yang dipersamakan dengan itu. Deposito mudharabah adalah simpanan dana dengan skema pemilik dana (shahibul maal) mempercayakan dananya untuk dikelola bank (mudharib) dengan hasil yang diperoleh dibagi antara pemilik dana dan bank dengan nisbah yang disepakati sejak awal.6

Dana yang dihimpun oleh bank haruslah di salurkan kepada masyarakat tujuannyan untuk mendapatakan keuntungan bagi bank dan untuk membiayai kegiatan oprasiaonal bank sendiri. Penyaluran dana bank syariah diberikan dalam bentuk pembiayaan dan diliahat dari segi bentuknya pembiayan dalam perbankan syariah dapat dibagi tiga, yaitu bentuk pembiayan yang secara komersial menguntungkan, bentuk yang kedua yaitu pembiayaan yang tidak untuk mencari keuntungan yang lebih ditujukan kepada orang yang membutuhkan, dan yang ketiga yaitu bentuk pembiayan yang memang diberikan kepada orang miskin dan membutuhkan. ${ }^{7}$

Pembiayaan berdasarkan prinsip syariah adalah penyediaan uang atau tagihan yang dapat dipersamakan dengan itu, berdasarkan persetujuan atau kesepakatan anatara bank dengan pihak lain yang mewajibkan pihak-pihak yang dibiayai untuk mengembalikan uang atau tagihan tersebut setelah jangka waktu tertentu dengan imbalan atau bagi hasil. ${ }^{8}$ Penyaluran dana bank syariah dilakukan dengan pembiayaan baik menggunakan skema jual beli maupun skema investasi. Skema jual beli memiliki beberapa bentuk, yaitu murabahah, salam dan istishna. Adapun pembiayaan murabahah merupakan akad jual beli dengan menyatakan harga perolehan dan keuntungan yang disepakati oleh penjual dan pembeli. ${ }^{9}$

Dalam fiqih islam, murabahah menggambarkan suatu jenis penjualan. Dalam transaksi murabahah, penjual sepakat dengan pembeli untuk menyediakan suatu produk, dengan ditambah jumlah keuntungan

${ }^{6}$ Ibid, hlm. 61

${ }^{7}$ Ascarya, Akad Dan Produk Bank Syariah, (Jakarta: PT Raja Grafindo Persada, 2012), hlm.122

${ }^{8}$ Andrian Sutedi, Perbankan Syariah, (Bogor: Ghalia Indonesia,2009), hlm 68

${ }^{9}$ Hendi Suhendi. Fiqh Muamalah, hlm. 62 
yang hendkak diambilnya. Pembayaran dapat dilakukan saat penyerahan barang atau ditetapkan pada tanggal tertentu yang disepakati. Murabahah dapat dilakukan berdasarkan pesanan atau tanpa pesanan. Apabila berdasarkan pesanan, bank melakukan pembelian barang setelah ada pesanan dari nasabah, sedangkan tanpa pesanan bank membeli persedian barang tanpa ada pesanan terlebih dahulu. ${ }^{10}$

Bank Pembiayaan Rakyat Syariah (BPRS) adalah bank syariah yang dalam kegiatannya tidak memberikan jasa dalam lalu lintas pembayaran. ${ }^{11}$ Bentuk hukum dari Bank Pembiayaan Rakyat Syariah (BPRS) dapat berupa perseroan terbatas, koprasi atau perusahaan daerah. Tabungan Wadiah dan Dana Investasi Tidak Terikat merupakan salah satu produk penghimpunan dana yang paling berpengaruh terhadap pendanaan di Bank Pembiayaan Rakyat Syariah dibanding dengan produk penghimpunan dana lainnya.

PT BPRS Gotong Royong Subang merupakan satu-satunya perusahaan yang didirikan PEMDA Kabupaten Subang yang bergerak dalam perbankan syariah di provinsi Jawa Barat. Cikal bakal berdirinya PT BPRS Gotong Royong Subang adal ah dari program PPK-IPM (Program Pendanaan Kompetisi-Indeks Pembangunan Manusia) yang telah selesai masa tugasnya pada tahun 2008.

Dana yang telah dihimpun kemudian disalurkan dalam bentuk pembiayaan, salah satunya dalam bentuk pembiayaan murabahah atau di Bank Pembiayaan Rakyat Syariah sering disebut Piutang Murabahah yang porsi pengalokasiannya paling besar dari total keseluruhan pembiayaan yang disalurkan. Di bawah ini merupakan data perkembangan Tabungan Wadiah, Dana Investasi Tidak Terikat dan Piutang Murabahah yang ada di PT. BPRS Gotong Royong selama periode 20142016.

\section{Tabel 1}

Perkembangan Jumlah Tabungan Wadiah, Dana Inewstasi Tidak Terikat dan Piutang Murabahah PT. BPRS Gotong Royong Subang 2014-2016

\begin{tabular}{|c|c|c|c|c|c|c|c|}
\hline \multirow{2}{*}{ Tahun } & \multicolumn{2}{|c|}{ Tabungan Wadiah } & \multicolumn{2}{c|}{$\begin{array}{c}\text { Dana Investasi Tidak } \\
\text { Terikat }\end{array}$} & \multicolumn{2}{c|}{ Piutang Murabahah } \\
\cline { 2 - 8 } & & $\left(\mathbf{X}_{\mathbf{1}}\right)$ & $\mathbf{\%}$ & $\mathbf{( \mathbf { X } _ { 2 } )}$ & $\mathbf{\%}$ & (Y) & \% \\
\hline \multirow{2}{*}{2014} & I & 497.985 & 4,31 & 117.196 & 0,18 & 563.500 & 0,59 \\
\cline { 2 - 8 } & II & $\mathbf{4 4 5 . 1 1 8}$ & $\mathbf{3 , 8 5}$ & 384.818 & 0,60 & $\mathbf{2 . 6 6 7 . 9 4 6}$ & $\mathbf{2 , 8 1}$ \\
\hline
\end{tabular}

${ }^{10}$ Andrian Sutedi, Perbankan Syariah, (Bogor: Ghalia Indonesia, 2009), hlm 99

11 Pasal 1 UU No. 21 Tahun 2008 tentang Perbankan Syariah 


\begin{tabular}{|c|c|c|c|c|c|c|c|}
\hline & III & 755.955 & 6,54 & 965.810 & 1,50 & 3.997 .282 & 4,21 \\
\cline { 2 - 8 } & IV & 874.843 & 7,56 & 2.120 .246 & 3,29 & 6.388 .682 & 6,72 \\
\hline \multirow{4}{*}{2015} & I & 1.382 .024 & 11,95 & 2.518 .775 & 3,91 & 8.146 .144 & 8,57 \\
\cline { 2 - 8 } & II & $\mathbf{7 9 1 . 9 0 1}$ & $\mathbf{6 , 8 5}$ & 3.474 .161 & 5,40 & $\mathbf{9 . 8 4 0 . 2 9 3}$ & $\mathbf{1 0 , 3 6}$ \\
\cline { 2 - 8 } & III & 1.094 .742 & 9,47 & 4.813 .252 & 7,48 & 10.357 .159 & 10,90 \\
\cline { 2 - 8 } & IV & $\mathbf{9 3 1 . 8 7 2}$ & $\mathbf{8 , 0 6}$ & 8.558 .808 & 13,30 & 10.696 .033 & 11,26 \\
\hline \multirow{4}{*}{2016} & I & 959.320 & 8,29 & 9.101 .066 & 14,14 & $\mathbf{1 0 . 1 0 1 . 0 2 3}$ & $\mathbf{1 0 , 6 3}$ \\
\cline { 2 - 8 } & II & 1.047 .598 & 9,06 & $\mathbf{8 . 5 1 3 . 3 5 6}$ & $\mathbf{1 3 , 2 3}$ & $\mathbf{1 0 . 3 4 8 . 0 6 7}$ & $\mathbf{1 0 , 8 9}$ \\
\cline { 2 - 8 } & III & 1.383 .826 & 11,96 & 10.558 .476 & 16,41 & 10.521 .871 & 11,08 \\
\cline { 2 - 8 } & IV & 1.400 .827 & 12,11 & 13.229 .977 & 20,56 & 11.372 .556 & 11,97 \\
\hline
\end{tabular}

Sumber: www.bi.com (data diolah 2017)

Berdasarkan tabel diatas dapat dilihat bahwa perkembangan Tabungan wadi'ah selama tiga periode mengalami fluktuasi, sedangakan Dana Investasi Tidak Terikat mengalami pertumbuhan yang signifikan begitupun dengan perkembanan piutang murabahah. Selama tiga periode Tabungan Wadiah mengalami penurunan yaitu pada tahun 2014 triwulan ke-2 dan pada tahun 2015 triwulan ke-2 dan ke-4. Sedangkan Dana Investasi Tidak Terikat dan piutang murabahah hanya mengalami penurunan pada tahun 2016 triwulan ke-2 dan tahun 2016 triwulan ke-1.

Untuk rincian lebih jelasnya dapat dilihat perkembangan Tabungan Wadiah, Dana Investasi Tidak Terikat dan Piutang Murabahah PT. BPRS Gotong Royong selama periode 2014-2016 dalam bentuk grafik di bawah ini:

\section{Gambar 1}

Perkembangan Jumlah Tabungan Wadiah, Dana Investasi Tidak Terikat dan Piutang Murabahah PT. BPRS Gotong Royong Subang 2014-2016
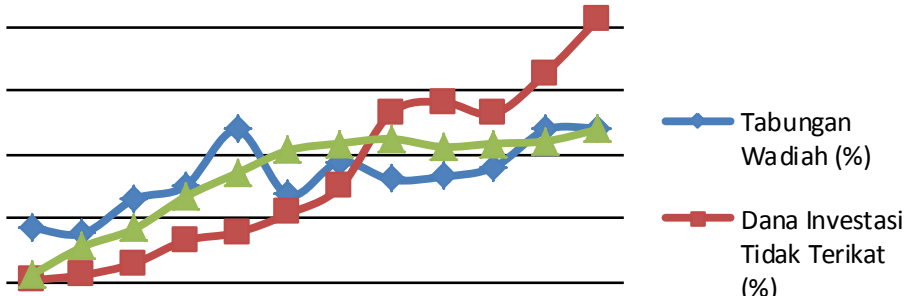

(\%) 
Dari grafik di atas bahwa perkembangan Tabungan Wadiah selama tiga tahun berjalan mengalami fluktuasi, pada tahun 2014 triwulan pertama sebesar $4,31 \%$ dan mengalami penurunan pada triwulan ke-2 menjadi 3,85\% kembali meningkat pada triwulan ke-3 menjadi 6,54\% dan kembali meningkat pada triwulan ke-4 menjadi 7,56\%. Tahun 2015 triwulan pertama Tabungan Wadiah sebesar $11,95 \%$ dan pada triwulan ke-2 mengalami penurunan menjadi $6,85 \%$, dan mengalami peningkatan pada triwulan ke-3 menjadi $9,47 \%$ dan kembali menurun pada triwulan ke-4 menjadi 8,06\%. Pada tahun 2016 yang pada triwulan pertama Tabungan Wadiah sebesar 8,29\%, mengalami penurunan pada triwulan ke-2 menjadi 9,06\%, dan mengalami peningkatan pada triwulan ke-3 menjadi $11,96 \%$ dan kembali mengalami peningkatan pada triwulan ke-4 menjadi $12,11 \%$.

Adapun perkembangan dari Dana Investasi Tidak Terikat pada tahun 2014 triwulan pertama sebesar $0,18 \%$ dan terus mengalami peningkatan pada triwulan ke-2, ke-3 dan ke-4 dengan nilai masingmasing sebesar 0,60\%, 1,50\%, dan 3,29\%. Pada tahun 2015 triwulan pertama Tabungan Wadiah sebesar 3,91\%, dan pada triwulan ke-2 mengalami peningkatan begitu pula pada triwulan ke-3 dan ke-4 dengan nilai masing-masing sebesar 5,40\% 7,48\% dan 13,30\%. Pada tahun 2016 triwulan pertama Tabungan Wadiah sebesar 14,14\%, dan pada triwulan ke-2 mengalami penurunan menjadi 13,23\%, dan kembali meningkat pada triwulan ke-3 menjadi $16,41 \%$ dan kembali mengalami peningkatan pada triwulan ke-4 menjadi $20,56 \%$.

Pertumbuhan pembiayaan murabahah selama tiga periode terus mengalami peningkatan hanya terjadi penurunan pada tahun 2016 triwulan pertama, jika dilihat dari grafik di atas terdapat ketidak sesuaian antara pertumbuhan Piutang Murabahah yang seharusnya perkembangannya sejalan dengan besar kecilnya dana yang dihimpun (Tabungan Wadiah dan Dana Investasi Tidak Terikat).

Secara teori, penghimpunan dana sangat berkaitan dengan penyaluran pembiayaan dan usaha yang dilakukan perbankan syariah dalam mengelola dana yang diterima dari aktivitas funding untuk disalurkan kepada aktivitas fiinancing. ${ }^{12}$ Merujuk pada pernyataan tersebut didapat suatu pemahaman apabila jumlah dana yang dihimpun besar maka pembiayaan yang disalurkan akan besar juga begitupun

12 Zainul Arifin, Dasar-Dasar Manajemen Bank Syariah, (Jakarta:AlvaBet, 2002), hlm.51 
sebaliknya. Akan tetapi ketidak sesuian tersebut tentunya dipengaruhi oleh beberapa faktor lain.

\section{B. Analisis Deskriptif}

Analisi ini menjelaskan gamabaran terkait dengan Tabungan Wadiah $\left(\mathrm{X}_{1}\right)$ dana investasi tidak terikat $\left(\mathrm{X}_{2}\right)$ dan Piutang Murabahah (Y), yang terjadi pada PT BPRS Gtong Royong Subang dalam kurun waktu tiga tahun yakni pada tahun 2014-2016. Tujuaan dari analisis ini ialah untuk mengetahui besaran dari ketiga variabel tersebut baik tinggi rendah atau yang lainnya. Oleh karena itu untuk mengukur keakuratan dalam menghitungnya dibantu dengan aplikasi SPSS For Windows Versi 22.00, dibawah ini merupakan data secara keseluruhan untuk analisis statistik.

Tabel 2

Perhitungan Jumlah Tabungan Wadiah dan Dana Investasi Tidak Terikat terhadap Piutang Murabahah PT. BPRS Gotong Royong Subang 2014-2016

\begin{tabular}{|c|c|c|c|c|c|c|c|c|}
\hline$x_{1}$ & $x_{2}$ & Y & $x_{1}^{2}$ & $x_{2}^{2}$ & $y^{2}$ & $X_{1} . Y$ & $X_{2} \cdot Y$ & $x_{1} \cdot x_{2}$ \\
\hline 497.985 & 117.196 & 563.5 & 247.989 .060 .225 & 13.734.902.416 & 377.532 .250 .000 & 280.614 .547 .500 & 66.039 .946 .000 & 58.361850 .060 \\
\hline 445.118 & 384.818 & 2.667 .946 & 198.130 .033 .924 & 148.084 .893 .124 & 7.117.935.858.916 & 1.187 .550 .787 .628 & 1.026 .673 .643 .828 & 171.289.418.524 \\
\hline 755.955 & 965.81 & 3.997 .282 & 571.467 .962 .025 & 932.788 .956 .100 & 15.978.263.387.524 & 3.021 .765 .314 .310 & 3.860 .614 .928 .420 & 730.108 .898 .550 \\
\hline 874.843 & 2.120 .246 & 6.388 .682 & 765.350 .274 .649 & 4.495 .443 .100 .516 & 40.815 .257 .697 .124 & 5.589 .093 .726 .926 & 13.545.577.455.772 & 1.854.882.371.378 \\
\hline 1.382 .024 & 2.518 .775 & 8.146 .144 & 1.909 .990 .336 .576 & 6.344.227.500.625 & 66.359.662.068.736 & 11.258.166.515.456 & 20.518 .303 .853 .600 & 3.481 .007 .500 .600 \\
\hline 791.901 & 3.474 .61 & 9.840 .293 & 627.107 .193 .801 & 12.069.794.653.921 & 96.831.366.325.849 & 77.792 .537 .866 .993 & 34.186 .762 .169 .173 & 2.751 .191 .570 .061 \\
\hline 1.094 .742 & 4.813.252 & 10.357.159 & 1.198.460.046.564 & 23.167.394.815.504 & 107.270.742.551.281 & 11.338 .416 .957 .978 & 49.851.616.271.068 & 5.269 .269 .120 .984 \\
\hline 931.872 & 8.558 .808 & 10.696 .033 & 868.385 .424 .384 & 73.253.194.380.864 & 114.405.12.937.089 & 9.967 .333 .663 .776 & 91.545.292.808.664 & 7.975.713.528.576 \\
\hline 959.32 & 9.101 .066 & 10.101.023 & 920.294 .862 .400 & 82.829.402.336.356 & 102.030.665.646.529 & 9.690 .1113 .384 .360 & 91.930 .076 .990 .518 & 8.730 .834 .635 .120 \\
\hline 1.047 .598 & 8.513 .356 & 10.348.067 & 1.097.461.569.604 & 72.477.230.382.736 & 107.082 .490 .636 .489 & 10.840.614.293.066 & 88.096.778.282.852 & 8.918 .574 .718 .888 \\
\hline 1.383 .826 & 10.558 .476 & 10.521 .871 & 1.914.974.398.276 & 111.481.415.442.576 & 110.709.769.340.641 & 14.560 .438 .658 .446 & 111.094.922.428.596 & 14.611.093.609.176 \\
\hline 1.400 .827 & 13.229.977 & 11.372 .556 & 1.962.316.283.929 & 175.032.291.420.529 & 129.335.029.973.136 & 15.930 .983 .503 .812 & 150.458 .654 .311 .212 & 18.532.908.990.979 \\
\hline$\sum X_{1}=11.566 .011$ & $\sum X_{2}=64.355 .941$ & $\Sigma^{Y}=95.000 .556$ & $\begin{array}{c}\sum X_{1}{ }^{2}= \\
12.281 .927 .446 .3 \\
57\end{array}$ & $\begin{array}{c}{\left[X_{2}{ }^{2}=\right.} \\
562.245 .002 .785 . \\
270\end{array}$ & $\begin{array}{c}\Sigma Y^{2}= \\
898.253 .837 .673 . \\
310\end{array}$ & \begin{tabular}{|c|}
$X_{1}, Y=$ \\
101.457 .629 .220$. \\
251
\end{tabular} & \begin{tabular}{|c|}
$\sum X_{2} \cdot Y=$ \\
656.181 .313 .089 .7 \\
03
\end{tabular} & $\begin{array}{c}\Sigma X_{1} \cdot X 2= \\
73.085 .236 .212 .8 \\
96\end{array}$ \\
\hline
\end{tabular}

Sumber: www.bi.com (data diolah 2017)

Keterangan: $\quad \mathrm{X}_{1}=$ Tabungan Wadiah

$\mathrm{X}_{2}=$ Dana Investasi Tidak Terikat

$\mathrm{Y}=$ Piutang Murabahah

Berikut merupakan statistik deskriptif dengan mengunakan SPSS For Windows Versi 22. 
Tabel 3

Statistik Deskriftif Jumlah Tabungan Wadiah dan Dana Investasi Tidak Terikat terhadap Piutang Murabahah PT. BPRS Gotong Royong Subang 2014-2016 (Descriptive statistics)

\begin{tabular}{|c|c|c|c|c|c|}
\hline & $\mathrm{N}$ & Minimum & Maximum & Mean & $\begin{array}{c}\text { Std. } \\
\text { Deviation }\end{array}$ \\
\hline $\begin{array}{l}\text { Tabungan Wadiah } \\
\text { Dana Investasi Tidak } \\
\text { Terikat } \\
\text { Piutang Murabahah } \\
\text { Nalid N (listwise) }\end{array}$ & $\begin{array}{l}12 \\
12 \\
12 \\
12\end{array}$ & $\begin{array}{l}445118 \\
117196 \\
563500\end{array}$ & $\begin{array}{c}1400827 \\
13229977 \\
11372556\end{array}$ & $\begin{array}{c}963834,3 \\
5362995,1 \\
7916713\end{array}$ & $\begin{array}{c}556466,5 \\
3096323,2 \\
4570712,9\end{array}$ \\
\hline
\end{tabular}

Sumber : Software SPSS Versi 22.00 For Windows (diolah 2017)

Berdasarkan tabel 4.2 hasil perhitungan SPSS For Windows Versi 22.00 menunjukan $\mathrm{N}$ merupakan banyaknya sampel yang digunakan dalam penelitian yakni 12 dari variabel independen yaitu Tabungan Wadiah dan Dana Investasi Tidak Terikat, variabel dependen yaitu Piutang Murabahah. Nilai minimum dari Tabungan Wadiah adalah sebesar 445.118 sedangkan nilai minimum Dana Investasi Tidak Terikat sebesar 117.196 adapun nilai minimum Piutang Murabahah sebesar 563.500.

Nilai maxsimum dari Tabungan Wadiah sebesar 1.400.827, sedangkan nilai maxsimum Dana Investasi Tidak Terikat sebesar 13.229.977, adapun nilai maxsimum Piutang Murabahah sebesar 11.372.556. Nilai mean dari Tabungan Wadiah sebesar 963.834,3, sedangkan nilai mean Dana Investasi Tidak Terikat sebesar 5.362.995,1, adapun nilai mean Piutang Murabahah sebesar 7.916.713. Nilai standar deviasi dari Tabungan Wadiah sebesar 556.466,5, sedangkan nilai standar deviasi Dana Investasi Tidak Terikat sebesar 3.096.323,2, adapun nilai standar deviasi Piutang Murabahah sebesar 4.570.712,9.

\section{Pengaruh Jumlah Tabungan Wadiah dan Dana Investasi Tidak Terikat terhadap Jumlah Piutang Murabahah pada PT. BPRS Gotong Royong $\mathrm{X}_{1} \mathrm{X}_{2} \mathrm{Y}$}

\section{1) Regresi Berganda}

Analisis regresi berganda digunakan untuk memprediksi keadaan (naik turunnya) variabel terikat. Apabila dua atau lebih variabel tidak terikat seebagai faktor prediktor dimanipulasi (dinaik turunkan nilainya). Pada tulisan ini peneliti ditunjukkan hasil analisis pengaruh 
antara Tabungan Wadiah dan Dana Investasi Tidak Terikat terhadap Piutang Murabahah dengan perhitungan sebagai berikut:

$$
\mathrm{Y}=\mathrm{a}+\mathrm{b}_{1} \mathrm{X}_{1}+\mathrm{b}_{2} \mathrm{X}_{2}
$$

Sebelum menghitung persamaan regresi berganda terlebih dahulu di hitung perhitungan sebagai berikut:

$$
\begin{aligned}
& \sum X_{1}{ }^{2}=\sum X_{1}^{2}-\frac{\left(\sum X_{1}\right)^{2}}{n} \\
& \sum X_{1}{ }^{2}=12.281 .927 .446 .357-\frac{(11.566 .011)^{2}}{12} \\
& \sum X_{1}{ }^{2}=12.281 .927 .446 .357-\frac{133.772 .610 .452 .121}{12} \\
& \sum X_{1}{ }^{2}=12.281 .927 .446 .357-11.147 .717 .537 .676,7
\end{aligned}
$$

$\sum X_{1}^{2}=1.134 .209 .908 .680,3$

$\sum X_{2}^{2}=\sum X_{2}^{2}-\frac{\left(\sum X_{2}\right)^{2}}{n}$

$\sum X_{2}^{2}=562.245 .002 .785 .270-\frac{(64.355 .941)^{2}}{12}$

$\sum X_{2}{ }^{2}=562.245 .002 .785 .270-\frac{4.141 .687 .141 .995 .480}{12}$

$\sum X_{2}{ }^{2}=562.245 .002 .785 .270-345.140 .595 .166 .290$

$\sum X_{2}{ }^{2}=217.104 .407 .618 .980$

$$
\begin{aligned}
& \sum Y^{2}=\sum Y^{2}-\frac{\left(\sum Y\right)^{2}}{n} \\
& \sum Y^{2}=898.253 .837 .673 .310-\frac{(95.000 .556)^{2}}{12}
\end{aligned}
$$$$
\sum Y^{2}=898.253 .837 .673 .310-\frac{9.025 .105 .640 .309 .140}{12}
$$$$
\sum Y^{2}=898.253 .837 .673 .310-752.092 .136 .692 .428
$$$$
\sum Y^{2}=146.161 .700 .980 .882
$$

$$
\begin{aligned}
& \sum X_{1} Y=\sum X_{1} Y-\frac{\left(\sum X_{1}\right)\left(\sum Y\right)}{n} \\
& \sum X_{1} Y=101.457 .629 .220 .251-\frac{(11.566 .011)(95.000 .556)}{12} \\
& \sum X_{1} Y=101.457 .629 .220 .251-\frac{1.098 .777 .475 .702 .120}{12} \\
& \sum X_{1} Y=101.457 .629 .220 .251-91.564 .789 .641 .843 \\
& \sum X_{1} Y=9.892 .839 .578 .408
\end{aligned}
$$




$$
\begin{aligned}
& \sum X_{2} Y=\sum X_{2} Y-\frac{\left(\sum X_{2}\right)\left(\sum Y\right)}{n} \\
& \sum X_{2} Y=656.181 .313 .089 .703-\frac{(64.355 .941)(95.000 .556)}{12} \\
& \sum X_{2} Y=656.181 .313 .089 .703-\frac{6.113 .850 .176 .903 .200}{12} \\
& \sum X_{2} Y=656.181 .313 .089 .703-509.487 .514 .741 .933 \\
& \sum X_{2} Y=146.693 .798 .347 .770 \\
& \sum X_{1} X_{2}=\sum X_{1} X_{2}-\frac{\left(\sum X_{1}\right)\left(\sum X_{2}\right)}{n} \\
& \sum X_{1} X_{2}=73.085 .236 .212 .896-\frac{(11.566 .011)(64.355 .941)}{12} \\
& \sum X_{1} X_{2}=73.085 .236 .212 .896-\frac{744.341 .521 .521 .351}{12} \\
& \sum X_{1} \zeta_{2}=73.085 .236 .212 .896-62.028 .460 .126 .779,2 \\
& \sum X_{1} X_{2}=11.056 .776 .086 .116,7
\end{aligned}
$$

Selanjutnya adalah mencari nilai a dan b sebagai berikut:

$$
\begin{aligned}
& a=\frac{\left(\sum Y\right)-b_{1} \sum X_{1}-b_{2} \sum X_{2}}{n} \\
& a=\frac{(95.000 .556)-(4,240825727)(11.566 .011)-(0,459704798)(64.355 .941)}{12} \\
& a=\frac{95.000 .556-49.049 .437,01-29.584 .734,86}{12} \\
& a=\frac{16.366 .384,13}{12} \\
& a=1.363 .865,344 \\
& b_{1}=\frac{\left(\sum X_{2}^{2}\right)\left(\sum X_{1} Y\right)-\left(\sum X_{1} X_{2}\right)\left(\sum X_{2} Y\right)}{\left(\sum X_{1}^{2}\right)\left(\sum X_{2}^{2}\right)-\left(\sum X_{1} X_{2}\right)^{2}} \\
& \text { 僄 } \\
& =\frac{(217.104 .407 .618 .980)(9.892 .839 .578 .408)-(11.056 .776 .086 .116,7)(146.693 .798 .347 .770)}{(1.134 .209 .908 .680,3)(217.104 .407 .618 .980)-(11.056 .776 .086 .116 .7)^{2}} \\
& (1.134 .209 .908 .680,3)(217.104 .407 .618 .980)-(11.056 .776 .086 .116,7)^{2} \\
& b_{1} \\
& =\frac{2.147 .779 .076 .339 .870 .000 .000 .000 .000-1.621 .960 .481 .553 .250 .000 .000 .000 .000}{246.241 .970 .339 .614 .000 .000 .000 .000-122.252 .297 .418 .522 .000 .000 .000 .000} \\
& b_{1}=\frac{525.818 .594 .786 .619 .000 .000 .000 .000}{123.989 .672 .921 .092 .000 .000 .000 .000} \\
& b_{1}=4,240825727 \text { atau } 4,241 \\
& b_{2}=\frac{\left(\sum X_{1}^{2}\right)\left(\sum X_{2} Y\right)-\left(\sum X_{1} X_{2}\right)\left(\sum X_{1} Y\right)}{\left(\sum X_{1}^{2}\right)\left(\sum X_{2}^{2}\right)-\left(\sum \text { 崖 } X_{2}\right)^{2}} \\
& b_{2}=\frac{(1.134 .209 .908 .680,3)(146.693 .798 .347 .770)-(11.056 .776 .086 .116,7)(9.892 .839 .578 .408)}{(1.134 .209 .908 .680,3)(217.104 .407 .618 .980)-(11.056 .776 .086 .116,7)^{2}} \\
& b_{2}=\frac{166.381 .559 .627 .991 .000 .000 .000 .000-109.382 .912 .074 .330 .000 .000 .000 .000}{246.241 .970 .339 .614 .000 .000 .000 .000-122.252 .297 .418 .522 .000 .000 .000 .000}
\end{aligned}
$$




$$
\begin{aligned}
& b_{2}=\frac{56.998 .647 .553 .660 .200 .000 .000 .000}{123.989 .672 .921 .092 .000 .000 .000 .000} \\
& b_{2}=0,459704798 \text { atau } 0,460
\end{aligned}
$$

Hasil perhitungan di atas yang dilakukan secara manual menunjukan nilai konstanta (a) sebesar 1363865.344, koefisien regresi ( $b_{1}$ ) sebesar 4.241 dan kefisien regresi $\left(b_{2}\right)$ sebesar 0.460 sedangkan perhitungan dengan menggunakan aplikasi SPSS For Windows Versi 22.00 menunjukan hasil sebagai berikut:

Tabel 1.4

Analisis Regresi Jumlah Tabungan Wadiah dan Dana Investasi Tidak Terikat terhadap Piutang Murabahah PT. BPRS Gotong Royong Subang 2014-2016

\begin{tabular}{|c|c|c|c|c|c|c|}
\hline & \multirow[b]{2}{*}{ Model } & \multicolumn{2}{|c|}{ Unstandardized Coefficients } & $\begin{array}{c}\text { Standardized } \\
\text { Coefficients }\end{array}$ & \multirow[b]{2}{*}{$\mathrm{T}$} & \multirow[b]{2}{*}{ Sig. } \\
\hline & & B & Std. Error & Beta & & \\
\hline \multirow[t]{6}{*}{1} & (Constant) & 1363865.344 & 2072395.962 & & .658 & .527 \\
\hline & Dana & & & & & \\
\hline & Investasi & 460 & 193 & 560 & 2378 & 041 \\
\hline & Tidak & & & & & \\
\hline & Terikat & & & & & \\
\hline & $\begin{array}{l}\text { Tabungan } \\
\text { Wadiah }\end{array}$ & 4.241 & 2.675 & .374 & 1.586 & .147 \\
\hline
\end{tabular}

Coefficients ${ }^{\mathrm{a}}$

a. Dependent Variable: Piutang Murabahah

Sumber : Software SPSS Versi 22 For Windows (diolah 2017)

Tabel diatas menunjukan hasil yang sama dengan perhitungan secara manual yakni nilai konstanta (a) sebesar 1363865.344, koefisien regresi $\left(b_{1}\right)$ sebesar 4.241 dan kefisien regresi $\left(b_{2}\right)$ sebesar 0.460 , maka dari hasil berikut diperoleh persamaan regresi berganda sebagai berikut:

$$
\mathrm{Y}=\mathrm{a}+\mathrm{b}_{1} \mathrm{X}_{1}+\mathrm{b}_{2} \mathrm{X}_{2}
$$

Piutang Murabahah $=1363865.344+4.241$ Tabungan Wadiah + 0.460 Dana Investasi Tidak Terikat

Berdasarkan persamaan regresi berganda di atas didapat suatu kesimpulan sebagai berikut:

a) $\mathrm{a}=1363865.344$ 
Nilai di atas menunjukan jika jumlah Tabungan Wadiah dan Dana Investasi Tidak Terikat yang dihimpun sebesar 0, maka nilai Piutang Murabahah sebesar 1363865.344

b) $\mathrm{b}_{1}=4.241$

koefisien regresi $b_{1}$ menunjukan sebagai Tabungan Wadiah yakni sebesar 4.241, nilai tersebut dapat diartikan bahwa Tabungan Wadiah memiliki hubungan yang positif terhadap Piutang Murabahah dan menunjukan bahwa setiap Tabungan Wadiah mengalami kenaikan sebesar 1\% (diasumsikan semua variabel konstanta), maka Piutang Murabahah akan mengalami kenaiakn sebesar 4.241.

c) $\mathrm{b}_{2}=0.460$

koefisien regresi $b_{2}$ menunjukan sebagai Dana Investasi Tidak Terikat yakni sebesar 0.460 , nilai tersebut dapat diartikan bahwa Dana Investasi Tidak Terikat memiliki hubungan yang positif terhadap Piutang Murabahah dan menunjukan bahwa setiap Dana Investasi Tidak Terikat mengalami kenaikan sebesar 1\% (diasumsikan semua variabel konstanta), maka Piutang Murabahah akan mengalami kenaiakn sebesar 0.460 .

Berdasarkan uraian diatas, peneliti dapat menyimpulkan bahwa hasil peneltian Tabungan Wadiah dan Dana Investasi Tidak Terikat berpengaruh positif terhadap Piutang Murabahah. Dimana tingkat pengaruh Tabungan Wadiah terhadap Piutang Murabahah yaitu sebesar 4.241. dan tingkat pengaruh Dana Investasi Tidak Terikat terhadap Piutang Murabahah sebesar 0.460 .

Hasil penelitian ini didapat suatu rumusan bahwa setiap Tabungan Wadiah naik sebesar 1\% (diasumsikan semua variabel konstanta) maka Piutang Murabahah akan mengalami kenaiakn sebesar 4.241 dan setiap Dana Investasi Tidak Terikat mengalami kenaikan sebesar 1\% (diasumsikan semua variabel konstanta), maka Piutang Murabahah akan mengalami kenaiakn sebesar 0.460. Sehingga teori yang menyebutkan bahwa jika dana yang dihimpun besar dalam hal ini Tabungan Wadiah dan Dana Investasi Tidak terikat maka jumlah pembiayaan yang disalurkan besar dalam hal ini Piutang Murabahah, teori tersebut sesuai dengan hasil penelitan.

\section{2) Korelasi Berganda}

Analisis korelasi berganda digunakan untuk mengetahui hubungan antara dua variabel bebas terhadap variabel terikat secara bersamaan. Koefisien yang dihasilkan akan menunjukan seberapa kuat hubung- 
an antara variabel Tabungan Wadiah dan Dana Investasi Tidak Terikat terhadap Piutang Murabahah. Berikut hasil perhitungan analisis korelasi berganda yang dilakukan secara manual.

$$
r_{X 1 X 2 Y}=\sqrt{\frac{r_{X 1 Y}^{2}+r_{X 2 Y}^{2}-2\left(r_{X 1 Y}\right)\left(r_{X 2 Y}\right)\left(r_{X 1 X 2}\right)}{1-r_{X 1 X 2}^{2}}}
$$

Sebelum menghitung kepersamaan korelasi berganda di atas, terlebih mencari regresi untuk $\mathrm{X}_{1} \mathrm{X}_{2}$ seperti berikut:

$$
\begin{aligned}
& r_{X 1 X 2} \frac{n \sum X_{1} X_{2}-\left(\sum X_{1}\right)\left(\sum X_{2}\right)}{\sqrt{\left\{n \sum X_{1}^{2}-\left(\sum X_{1}\right)^{2}\right\}\left\{n \sum X_{2}^{2}-\left(\sum X_{2}\right)^{2}\right\}}} \\
& r_{X 1 X 2}=\frac{12(73.085 .236 .212 .896)-(11.566 .011)(64.355 .941)}{\sqrt{\left\{12(12.281 .927 .446 .357)-(11.566 .011)^{2}\right\}\left\{12(562.245 .002 .785 .270)-(64.355 .941)^{2}\right\}}} \\
& r_{X 1 X 2}=\frac{877.022 .834 .554 .752-744.341 .521 .521 .351}{\sqrt{\{147.383 .129 .356 .284-133.772 .610 .452 .121 爪 4.746 .940 .033 .423 .240-4.141 .687 .141 .995 .480\}}} \\
& r_{X 1 X 2}=\frac{132.681 .313 .033 .401}{\sqrt{(13.610 .518 .904 .163)(2.605 .252 .891 .427 .760)}} \\
& r_{X 1 X 2}=\frac{132.681 .313 .033 .401}{\sqrt{35.458 .843 .728 .902 .800 .000 .000 .000 .000}} \\
& r_{X 1 X 2}=\frac{132.681 .313 .033 .401}{188.305 .187 .737 .627} \\
& r_{X 1 X 2}=0,704607848
\end{aligned}
$$

Setelah diketahui nilai korelasi dari $\mathrm{X}_{1} \mathrm{X}_{2}$ maka untuk mengetahui nilai korelasi berganda dilakukan perhitungan seperti di bawah ini:

$$
\begin{aligned}
& r_{X 1 X 2 Y}=\sqrt{\frac{(0,768347)^{2}+(0,8234944)^{2}-2(0,768347)(0,8234944)(0,704607848)}{1-(0,704607848)^{2}}} \\
& r_{X 1 X 2 Y}=\sqrt{\frac{1,2685-0,891652275}{0,5035278}} \\
& r_{X 1 X 2 Y}=\sqrt{\frac{0,3768478645}{0,5035278}} \\
& r_{X 1 X 2 Y}=\sqrt{0,7484152879217} \\
& r_{X 1 X 2 Y}=0,865109986 \text { atau } 0,865
\end{aligned}
$$

Nilai 0,865109986 dari perhitungan manual di atas diperkuat dengan hasil perhitungan menggunakan aplikasi SPSS For Windows Versi 22.00 seperti tabel di bawah ini: 
Tabel 1.5

Analisis Korelasi Berganda Jumlah Tabungan Wadiah dan Dana Investasi Tidak Terikat terhadap Piutang Murabahah PT. BPRS Gotong Royong

Subang 2014-2016

Model Summary

\begin{tabular}{|l|c|r|r|r|}
\hline Model & $\mathrm{R}$ & R Square & Adjusted R Square & Std. Error of the Estimate \\
\hline 1 & $\mathbf{. 8 6 5}^{\mathbf{a}}$ & .748 & .693 & 2021332.05356 \\
\hline
\end{tabular}

a. Predictors: (Constant), Tabungan Wadiah, Dana Investasi Tidak Terikat

Sumber : Software SPSS Versi 22 For Windows (diolah 2017)

Dari tabil di atas dapat dilihat nilai koefisien korelasi Tabungan Wadiah dan Dana Investasi Tidak Terikat terhadap Piutang Murabahah sebesar 0,865, nilai ini menunjukan bahwa hubungan antara Tabungan Wadiah dan Dana Investasi Tidak Terikat terhadap Piutang Murabahah "sangat kuat" (lihat pedoman interpretasi pada tabel 4.9) serta menunjukan hubungan yang positif dan searah. Berdasarkan hasil perhitungan analisis korelasi yang telah dilakukan baik secara berganda maupun pervariabel dapat disimpulkan sebagai berikut:

Tabel 6

Koefisien Korelasi

\begin{tabular}{|c|c|c|}
\hline Variabel & Signifikasi & Keterangan \\
\hline $\begin{array}{c}\text { Tabungan Wadiah dan } \\
\text { Dana Investasi Tidak Terikat } \\
\text { terhadap Piutang Murabahah }\end{array}$ & 0,865 & Sangat Kuat \\
\hline
\end{tabular}

Dari tabel di atas dapat dilihat bahwa nilai koefisien Tabungan Wadiah dan Dana Investasi Tidak Terikat terhadap Piutang Murabahah sebesar 0.865 ini menunjukan hubungan yang tergolong "sangat kuat" dan searah atau positif. Hubungan yang positif menunjukan bahwa jika jumlah Tabungan Wadiah dan Dana Investasi Tidak Terikat meningkat maka jumlah Piutang Murabahah meningkat.

\section{3) Uji F}

Uji F dipakai untuk menguji tingkat signifikan dari Tabungan Wadiah dan Dana Investasi Tidak Terikat secara bersamaan terhadapa Piutang Murabahah, dengan membandingkan antara $\mathrm{F}_{\text {hitung }}$ dengan

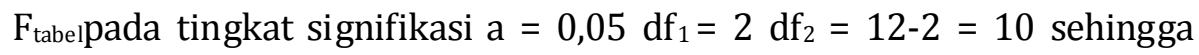
diperoleh nilai $\mathrm{F}_{\text {tabel }}$ sebesar 4,26 . Hipotesis yang diangkat ialah sebagai berilkut: 
Ho = Tabungan Wadiah dan Dana Investasi Tidak Terikat tidak berpengaruh secara signifikan terhadap Piutang Murabahah pada PT. BPRS Gotong Royong Subang

Ha = Tabungan Wadiah dan Dana Investasi Tidak Terikat berpengaruh secara signifikan terhadap Piutang Murabahah pada PT. BPRS Gotong Royong Subang.

Dengan acuan kriteria pengujian sebagai berikut:

$F_{\text {hitung }}>F_{\text {tabel }}$ maka Ho di tolak

$\mathrm{F}_{\text {hitung }}<\mathrm{F}_{\text {tabel }}$ maka Ho di terima

Menghitung $\mathrm{F}_{\text {hitung }}$ sebagai bahan untuk membandingkan dengan $\mathrm{F}_{\text {tabel }}$ yang dilakukan secara manual meliputi sebagai berikut:

$F=\frac{r^{2} / k}{\left(1-r^{2}\right) /(n-k-1)}$

$F=\frac{0,748415288 / 2}{(1-0,748415288) /(12-2-1)}$

$F=\frac{0,374207644}{0,251584712 / 9}$

$F=\frac{0,374207644}{0,027953857}$

$F=13,38661944$ atau 13,387

Berikut di bawah ini hasil perhitungan berdasarkan aplikasi SPSS For Windows Versi 22.00:

Tabel 7

Analisis Uji F Jumlah Tabungan Wadiah dan Dana Investasi Tidak Terikat terhadap Piutang Murabahah pada PT. BPRS Gotong Royong Subang Periode 2014-2016

\begin{tabular}{|c|l|c|c|c|c|c|}
\hline \multicolumn{9}{|c|}{ ANOVA $^{\mathrm{a}}$} \\
\hline 1 & \multicolumn{1}{|c|}{ Model } & \multicolumn{1}{|c|}{ Sum of Squares } & Df & Mean Square & F & Sig. \\
\hline 2 & Regression & $\mathbf{1 0 9 3 8 9 6 5 1 5 4 4 0 6 1 . 2 7 0}$ & $\mathbf{2}$ & $\mathbf{5 4 6 9 4 8 2 5 7 7 2 0 3 0 . 6 3 0}$ & $\mathbf{1 3 . 3 8 7}$ & $\mathbf{. 0 0 2}^{\mathrm{b}}$ \\
\hline 3 & Residual & $\mathbf{3 6 7 7 2 0 4 9 4 3 6 8 2 4 . 7 3 0}$ & $\mathbf{9}$ & $\mathbf{4 0 8 5 7 8 3 2 7 0 7 5 8 . 3 0 3}$ & & \\
\hline & Total & $\mathbf{1 4 6 1 6 1 7 0 0 9 8 0 8 8 6 . 0 0 0}$ & 11 & & & \\
\hline
\end{tabular}

a. Dependent Variable: Piutang Murabahah

b. Predictors: (Constant), Tabungan Wadiah, Dana Investasi Tidak Terikat

Sumber : Software SPSS Versi 22 For Windows (diolah 2017) 
Berdasarkan perhitungan manual yang kemudian diperkuat dengan perhitungan menggunakan aplikasi SPSS For Windows Versi 22.00 diatas, diperoleh nilai $F_{\text {hitung }}$ sebesar 13,387 dengan tingkat signifikan 0.002. Berdasarkan hasil tersebut maka Ho ditolak dan Ha diterima, karena nilai $F_{\text {hitung }}>F_{\text {tabel }}(13,387>4,26)$ dengan taraf signifikan 0,002 atau di bawah nilai probabilitas 0,05 $(0,002<0,05)$, maka dapat disimpulkan bahwa variabel Tabungan Wadiah dan Dana Investasi Tidak Terikat berpengaruh secara signifikan terhadap Piutang Murabahah pada PT. BPRS Gotong Royong Subang Periode 2014-2016.

Hasil pembuktian hipotesis dalam penelitian ini dapat dilihat pada gambar di bawah ini:

\section{Gambar 8}

\section{Hasil Pembuktian Hipotesis Tabungan Wadiah dan Jumlah Dana Investasi Tidak Terikat terhadap Piutang Murabahah}

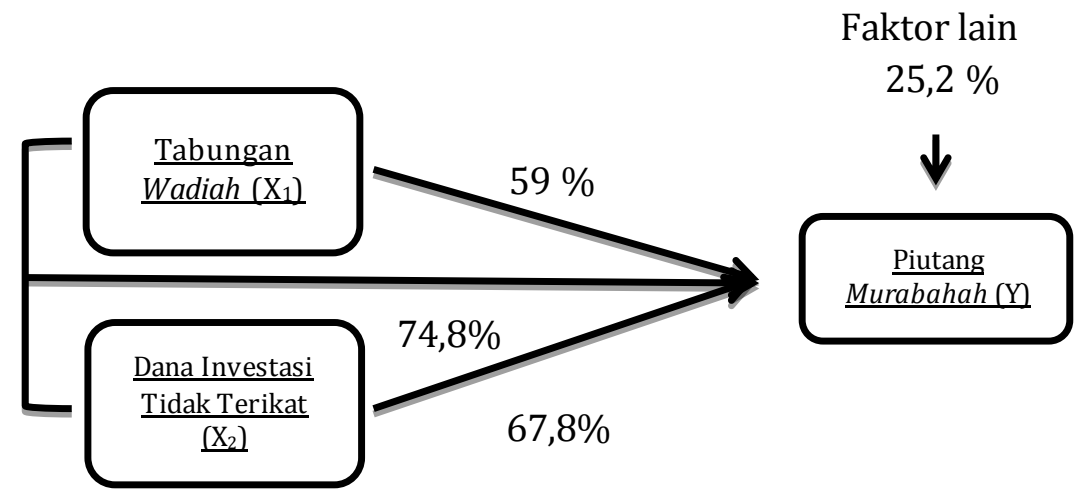

\section{Simpulan}

Berdasarkan hasil penelitian dan pembahasan mengenai Tabungan Wadiah dan Dana Investasi Tidak Terikat terhadap Piutang Murabahah, dapat disimpulkan bahwa hasil perhitungan secara simultan menunjukan $F_{\text {hitung }}>F_{\text {tabel }}$ yakni 13,387 $>$ 4,26 artinya Ho ditolak dan Ha diterima atau Tabungan Wadiah dan Dana Investasi Tidak Terikat berpengaruh secara signifikan terhadap Piutang Murabahah dengan tingkat pengaruh sebesar $74,8 \%$ dan sisanya dipengaruhi oleh faktor lain sebesar $25,2 \%$ yang tidak termasuk dalam penelitian ini. 


\section{DAFTAR PUSTAKA}

Andrian. 2009. Perbankan Syariah. Bogor : Ghalia Indonesia

Ascarya. 2012.Akad Dan Produk Bank Syariah. Jakarta: PT Raja Grafindo Persada

Ely dkk. 2008. Manajemen Perbankan Konvensional dan Syariah Malang : UIN Malang Press

Hendi. 2014. Fiqh Muamalah. Jakarta: PT Raja Grafindo Persada.

Ibnu al-Mundzir an-Naisaburi. 1999.al-Ijma'. Kairo: Maktabah al-Shafa Jalal al-Din Abd al-Rahman Ibnu Abi Bakr al-Suyuthi. 1987.al-Asybah wa al-Nazha'ir fi Qawa'id wa Furu' Fiqh al-Syafi'iyyah. Beirut: Dar alKitab al-'Arabi

Karim, Adiwarman.2011. Bank Islam. Jakarta: PT Raja Grafindo Persada Muhamamad.2002. Manajemen Bank Syariah. Yogyakarta: UPP-STIM YKPN

Muhammad Ibn Hibban Abu Hatim ad-Dharimin. 1993, Shahih Ibn HibbBitartib Ibn Balb, Arnauth Beirut: Muassasah ar-Risalah

Mulyani, Nyai Leli. 2015.Pengaruh Tabungan IB Siaga Bisnis dan Giro IB terhadap Laba Operasional pada PT Bank Syariah Bukopin, Tbk. Bandung: UIN Sunan Gunung Djati

Qosim, M. Rizal. 2009.Pengalaman Fiqih. Solo: PT Tiga Serangkai Pustaka Mandiri

Rizal dkk. 2007. Akuntansi Perbankan Syariah. Jakarta: Salemba Empat

Siwanto, Ely dkk. 2008.Manajemen Perbankan Konvensional Dan Syariah. Malang: UIN Malang Press

Soetanto Hadianoto. 2008.Bank Strategi On Funding and Liability Managemen. Jakarta: PT Gramedia

Sohran Sohari dan Rufah Abdullah. 2011. Fiqih Muamalah. Bogor: Ghali Indonesia

Sri Nurhayati dan Wasilah. 2015.Akuntansi Syariah di Indonesia. Jakarta: Salemba Empat

Sugiyono. 2013. Statistika untuk Penelitian. Bandung: Alfabeta.

Syekh Ahmad Ibn Syekh Muhammad al-Zarqa. 1987.Syarh al-Qawa'id alFiqhiyyah. Damaskus: Dar al-Qalam

Taswan. 2006. Manajemen Perbankan. Yogyakarta: UPP STIM YKPM Wiroso. 2005. Penghimpunan dana dan Distribusi Hasil Usaha Bank Syariah. Jakarta: Grasindo Widiasarna Indonesia 
60 |'Adliya Vol. 12, No. 1, Juni 2018

Yusuf al-Qardhawi. 2010.al-Qawa'id al-Hakimah li Fiqh al-Muamalat. Kairo: Dar al-Syuruq

Undang-Undang Nomor 21 Tahun 2008 tentang Perbankan Syariah

Undang-Undang Republik Indonesia Nomor 10 Tahun 1998 tentang Perbankan 